\title{
Regulation of reactive oxygen species-mediated abscisic acid signaling in guard cells and drought tolerance by glutathione
}

\section{Shintaro Munemasa ${ }^{1}$, Daichi Muroyama ${ }^{1}$, Hiroki Nagahashi ${ }^{2}$, Yoshimasa Nakamura ${ }^{1}$, Izumi C. Mori $^{3}$ and Yoshiyuki Murata ${ }^{1 *}$}

\author{
1 Division of Agricultural and Life Science, Graduate School of Environmental and Life Science, Okayama University, Okayama, Japan \\ ${ }^{2}$ Faculty of Agriculture, Okayama University, Okayama, Japan \\ ${ }^{3}$ Institute of Plant Science and Resources, Okayama University, Kurashiki, Japan
}

\section{Edited by:}

Nobuyuki Uozumi, Tohoku

University, Japan

\section{Reviewed by:}

Shan Lu, Nanjing University, China Jin Chen, Michigan State University, USA

\section{*Correspondence:}

Yoshiyuki Murata, Division of

Agricultural and Life Science,

Graduate School of Environmental

and Life Science, Okayama

University, 1-1-1 Tsushima-Naka,

Okayama 7008530, Japan

e-mail:muta@cc.okayama-u.ac.jp
The phytohormone abscisic acid (ABA) induces stomatal closure in response to drought stress, leading to reduction of transpirational water loss. A thiol tripeptide glutathione $(\mathrm{GSH})$ is an important regulator of cellular redox homeostasis in plants. Although it has been shown that cellular redox state of guard cells controls ABA-mediated stomatal closure, roles of GSH in guard cell ABA signaling were largely unknown. Recently we demonstrated that GSH functions as a negative regulator of ABA signaling in guard cells. In this study we performed more detailed analyses to reveal how GSH regulates guard cell ABA signaling using the GSH-deficient Arabidopsis mutant cad2-1. The cad2-1 mutant exhibited reduced water loss from rosette leaves. Whole-cell current recording using patch clamp technique revealed that the cad2-1 mutation did not affect ABA regulation of S-type anion channels. We found enhanced activation of $\mathrm{Ca}^{2+}$ permeable channels by hydrogen peroxide $\left(\mathrm{H}_{2} \mathrm{O}_{2}\right)$ in cad2-1 guard cells. The cad2-1 mutant showed enhanced $\mathrm{H}_{2} \mathrm{O}_{2}$-induced stomatal closure and significant increase of ROS accumulation in whole leaves in response to $A B A$. Our findings provide a new understanding of guard cell ABA signaling and a new strategy to improve plant drought tolerance.

Keywords: abscisic acid, glutathione, reactive oxygen species, guard cell, stomata

\section{INTRODUCTION}

A phytohormone abscisic acid (ABA) induces closing of stomatal pores on leaf epidermis, resulting in reduction of transpirational water loss. The central ABA signaling module is composed of $\mathrm{ABA}$ receptors $\mathrm{PYR} / \mathrm{PYL} / \mathrm{RCAR}$, clade A type $2 \mathrm{C}$ protein phosphatases (PP2Cs), and subclass 2 of Snf1-related kinases (SnRK2s) and regulates downstream targets (Fujii et al., 2009; Ma et al., 2009; Park et al., 2009) including ion channels (Geiger et al., 2009; Lee et al., 2009).

Activation of slow type (S-type) anion channels is a key step for ABA signaling in guard cells and drives depolarization of plasma membrane of guard cells, which in turn evokes $\mathrm{K}^{+}$extrusion (Linder and Raschke, 1992; Schroeder and Keller, 1992). A guard cell plasma membrane protein SLAC1 represents the Stype anion channel activity (Negi et al., 2008; Vahisalu et al., 2008). It has been demonstrated that ABA activation of S-type anion channels is mediated via a cytosolic $\mathrm{Ca}^{2+}$-dependent pathway (Marten et al., 2007; Siegel et al., 2009). ABA activates hyperpolarization-activated $\mathrm{Ca}^{2+}$-permeable cation $\left(\mathrm{I}_{\mathrm{Ca}}\right)$ channels in the plasma membrane of guard cells (Schroeder and Hagiwara, 1990; Hamilton et al., 2000; Pei et al., 2000; Kwak et al., 2003) and induces elevation of cytosolic free $\mathrm{Ca}^{2+}$ concentration $\left(\left[\mathrm{Ca}^{2+}\right]_{\mathrm{cyt}}\right)$ in guard cells (McAinsh et al., 1990; Schroeder and Hagiwara, 1990; Gilroy et al., 1991; Allan et al., 1994; Grabov and Blatt, 1998; Allen et al., 1999; Marten et al., 2007). The $\left[\mathrm{Ca}^{2+}\right]_{\mathrm{cyt}}$ signals are decoded by $\mathrm{Ca}^{2+}$ sensor proteins such as calcium dependent protein kinases (CDPKs). Electrophysiology experiments using Xenopus oocyte demonstrated that Arabidopsis CDPKs, CPK6, CPK21, and CPK23, directly phosphorylate and activate SLAC1 channel (Geiger et al., 2010; Brandt et al., 2012).

It has been suggested that guard cell ABA signaling involves redox regulation. Reactive oxygen species (ROS) including hydrogen peroxide $\left(\mathrm{H}_{2} \mathrm{O}_{2}\right)$ serve as a key mediator of ABA activation of $\mathrm{I}_{\mathrm{Ca}}$ channels (Pei et al., 2000; Murata et al., 2001; Kwak et al., 2003). Exogenous application of $\mathrm{H}_{2} \mathrm{O}_{2}$ activates $\mathrm{I}_{\mathrm{Ca}}$ channels and evokes guard cell $\left[\mathrm{Ca}^{2+}\right]_{c y t}$ increases (Pei et al., 2000). Plasma membrane $\mathrm{NAD}(\mathrm{P}) \mathrm{H}$ oxidases are responsible for $\mathrm{ABA}$-induced ROS production in guard cells (Kwak et al., 2003). Arabidopsis glutathione peroxidase 3 (AtGPX3) was shown to function as both a ROS scavenger and a ROS signal transducer in ABA signaling (Miao et al., 2006). Emerging evidences suggest that ROS production by apoplastic enzymes such as cell-wall bound peroxidases is also involved in induction of stomatal closure (An et al., 2008; Khokon et al., 2011; Hossain et al., 2013).

Glutathione (GSH) is the most abundant non-protein thiol compound in plants and a key regulator of cellular redox homeostasis. GSH is involved in various physiological processes including growth, development, and defense response to biotic and abiotic stresses (May et al., 1998; Noctor and Foyer, 1998). Previously we reported that ABA as well as methyl jasmonate 
(MeJA) decreases the GSH contents of guard cells (Akter et al., 2010; Okuma et al., 2011). Arabidopsis GSH-deficient mutants, chl-1 and cad2-1 exhibit enhanced ABA-induced and MeJAinduced stomatal closure and a membrane permeable derivative of GSH, GSH monoethyl ester (GSHmee) restored the stomatal phenotype of chl-1 and cad2-1 mutants (An et al., 2008; Akter et al., 2010, 2012, 2013; Okuma et al., 2011), demonstrating that $\mathrm{GSH}$ functions as a negative regulator of $\mathrm{ABA}$ and MeJA signaling in guard cells. However, the detailed mechanism of how GSH modulates the guard cell responses is still unclear.

In this study, we analyzed GSH regulation of ABA signaling in guard cells using the Arabidopsis GSH-deficient mutant cad21. The cad2-1 mutant is deficient in the first GSH biosynthesis enzyme, $\gamma$-glutamylcysteine synthetase. We found that the cad21 mutation causes enhanced ROS activation of $\mathrm{I}_{\mathrm{Ca}}$ channel and ABA-induced ROS accumulation in apoplast. A new signal model for regulation of ROS-mediated ABA signaling by GSH in guard cells is also proposed.

\section{MATERIALS AND METHODS PLANT MATERIAL AND GROWTH}

The Arabidopsis ecotype Columbia (Col) and cad2-1 mutant plants were grown on soil mixture of $70 \%(\mathrm{v} / \mathrm{v})$ vermiculite (Asahi-kogyo, Okayama, Japan) and 30\% (v/v) Sakata SupermixA (Sakata Seed Corporation, Yokohama, Japan) in growth chambers at $21^{\circ} \mathrm{C}$ under a 16-h-light/8-h-dark photoperiod with photon flux density of $80 \mu \mathrm{mol} \mathrm{m}{ }^{-2} \mathrm{~s}^{-1}$. Four- to six-week-old plants were used in all experiments.

\section{WATER LOSS ASSAY}

Three detached rosette leaves were placed on a plastic tray and the loss in fresh weight was monitored at the indicated times.

\section{STOMATAL APERTURE MEASUREMENTS}

Stomatal aperture measurements were performed as described previously (Munemasa et al., 2007; Okuma et al., 2011). Detached rosette leaves were floated on stomatal assay buffer containing $5 \mathrm{mM} \mathrm{KCl}, 50 \mu \mathrm{M} \mathrm{CaCl}_{2}$, and $10 \mathrm{mM}$ MES-Tris ( $\mathrm{pH}$ 5.6) for $2 \mathrm{~h}$ in the light to induce stomatal opening, followed by the addition of $\mathrm{H}_{2} \mathrm{O}_{2}$. After 2-h incubation in the light, the leaves were shredded and epidermal tissues were collected. At least 20 stomatal apertures were measured on each individual experiment.

\section{ELECTROPHYSIOLOGY}

Guard cell protoplasts (GCPs) were prepared from Arabidopsis rosette leaves by the enzymatic method, as described previously (Pei et al., 1997). Whole-cell currents were recorded using patch clamp technique, as described previously (Munemasa et al., 2007, 2011). For S-type anion current measurements, the pipette solution contained $150 \mathrm{mM} \mathrm{CsCl}, 2 \mathrm{mM} \mathrm{MgCl}_{2}, 6.7 \mathrm{mM}$ EGTA, $5.58 \mathrm{mM} \mathrm{CaCl}_{2}$ (free $\mathrm{Ca}^{2+}$ concentration: $2 \mu \mathrm{M}$ ), and $10 \mathrm{mM}$ HEPES-Tris ( $\mathrm{pH} 7.1$ ). The bath solution contained $30 \mathrm{mM} \mathrm{CsCl}$,

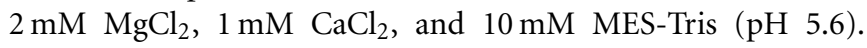
$5 \mathrm{mM} \mathrm{Mg}$-ATP was freshly added to the pipette solution before experiments. For $\mathrm{I}_{\mathrm{Ca}}$ current measurements, the pipette solution contained $10 \mathrm{mM} \mathrm{BaCl}_{2}, 4 \mathrm{mM}$ EGTA, and $10 \mathrm{mM}$ HEPES-Tris
( $\mathrm{pH}$ 7.1). The bath solution contained $100 \mathrm{mM} \mathrm{BaCl}_{2}$, and $10 \mathrm{mM}$ MES-Tris ( $\mathrm{pH}$ 5.6). $0.1 \mathrm{mM}$ DTT was added to both pipette and bath solutions freshly before experiments. In both cases, osmolarity was adjusted to $500 \mathrm{mmol} / \mathrm{kg}$ (pipette solutions) and $485 \mathrm{mmol} / \mathrm{kg}$ (bath solutions) with D-sorbitol.

\section{DETECTION OF ROS ACCUMULATION IN WHOLE LEAVES}

Accumulation of $\mathrm{H}_{2} \mathrm{O}_{2}$ in whole leaves was monitored using 3,3'diaminobenzidine (DAB) according to Maruta et al. (2010) with slight modifications. Detached rosette leaves were vacuum infiltrated with DAB assay buffer containing $1 \mathrm{mg} \mathrm{mL}^{-1} \mathrm{DAB}, 5 \mathrm{mM}$ $\mathrm{KCl}, 50 \mu \mathrm{M} \mathrm{CaCl}_{2}$, and $10 \mathrm{mM}$ MES-Tris (pH 5.6). Infiltrated leaves are incubated in $\mathrm{DAB}$ assay buffer with or without $\mathrm{ABA}$ for $4 \mathrm{~h}$ in the light. The leaves were then decolorized by boiling in ethanol. Apoplastic ROS were visualized as a reddish-brown color and quantified using Image-J software (National Institutes of Health, USA).

\section{STATISTICAL ANALYSIS}

All statistical significance was analyzed by double-tailed Student's $t$-test. We regarded differences at the level of $P<0.05$ as significant.

\section{RESULTS}

\section{THE cad2-1 MUTANT SHOWED ENHANCED DROUGHT TOLERANCE}

Previously we reported that GSH depletion by the cad2-1 mutation enhances ABA-induced stomatal closure in Arabidopsis (Okuma et al., 2011). To assess effect of the cad2-1 mutation on drought tolerance, we monitored water loss from detached rosette leaves. As shown in Figure 1, compared to wild type, the cad2-1 mutant exhibited reduced water loss from detached rosette leaves ( $P<0.018$ for Col vs. cad2-1 at 120 min after leaf detachment). This result suggests that the cad2-1 mutation improves drought tolerance.

\section{EFFECT OF THE cad2-1 MUTATION ON ABA REGULATION OF S-TYPE ANION CHANNELS.}

The cad2-1 mutation does not affect ABA activation of $\mathrm{I}_{\mathrm{Ca}}$ channels, suggesting that GSH functions downstream of $\left[\mathrm{Ca}^{2+}\right]_{\mathrm{cyt}}$

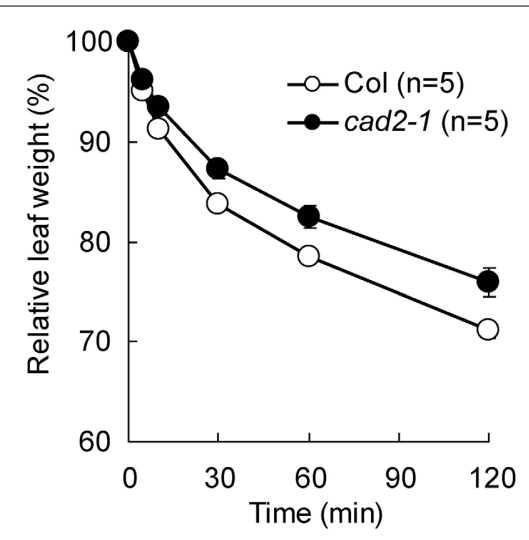

FIGURE 1 | The cad2-1 mutant shows reduced transpirational water loss. Fresh weight loss of detached rosette leaves. The bars represent the mean $\pm S E$ values of five independent replicates. 
elevation in guard cell ABA signaling (Okuma et al., 2011). Activation of S-type anion channel is mediated by $\left[\mathrm{Ca}^{2+}\right]_{\text {cyt }}$ elevation and considered as a crucial step for ABA-, MeJA-, and $\mathrm{CO}_{2}$-induced stomatal closure (Schroeder and Hagiwara, 1989; Pei et al., 1997; Munemasa et al., 2007; Hu et al., 2010). To confirm whether GSH depletion in the cad2-1 mutant affects ABA regulation of S-type anion channel activity, whole-cell patch-clamp analysis was performed. S-type anion currents were observed in wild-type GCPs pretreated with $10 \mu \mathrm{M}$ ABA $(P<0.023$ for Col Control vs. Col ABA at $-135 \mathrm{mV}$; Figure 2). We also found that ABA evoked S-type anion currents in cad2-1 GCPs to the same extent as in wild-type GCPs $(P<0.045$ for cad2-1 Control vs. cad2-1 ABA at $-135 \mathrm{mV}$; Figure 2). Note that in our experimental condition, free $\mathrm{Ca}^{2+}$ concentration in the pipette solution was buffered to $2 \mu \mathrm{M}$ and no obvious S-type anion currents were observed in both wild-type guard cells and cad2-1 guard cells without ABA pretreatment.

\section{THE cad2-1 MUTATION ENHANCED $\mathrm{H}_{2} \mathrm{O}_{2}$ ACTIVATION OF $\mathrm{I}_{\mathrm{Ca}}$ CHANNELS}

ABA activation of $\mathrm{I}_{\mathrm{Ca}}$ channels involves ROS as a second messenger (Pei et al., 2000; Murata et al., 2001; Kwak et al., 2003). Depletion of the major redox regulator, GSH, in the cad2-1 mutant might affect ROS-mediated ABA signaling in guard cells. Previously we demonstrated that ABA activation of $\mathrm{I}_{\mathrm{Ca}}$ channels is not enhanced in cad2-1 guard cells (Okuma et al., 2011). However, ROS activation of $\mathrm{I}_{\mathrm{Ca}}$ channels in cad2-1 guard cells was not yet analyzed. We examined effects of the cad2-1 mutation

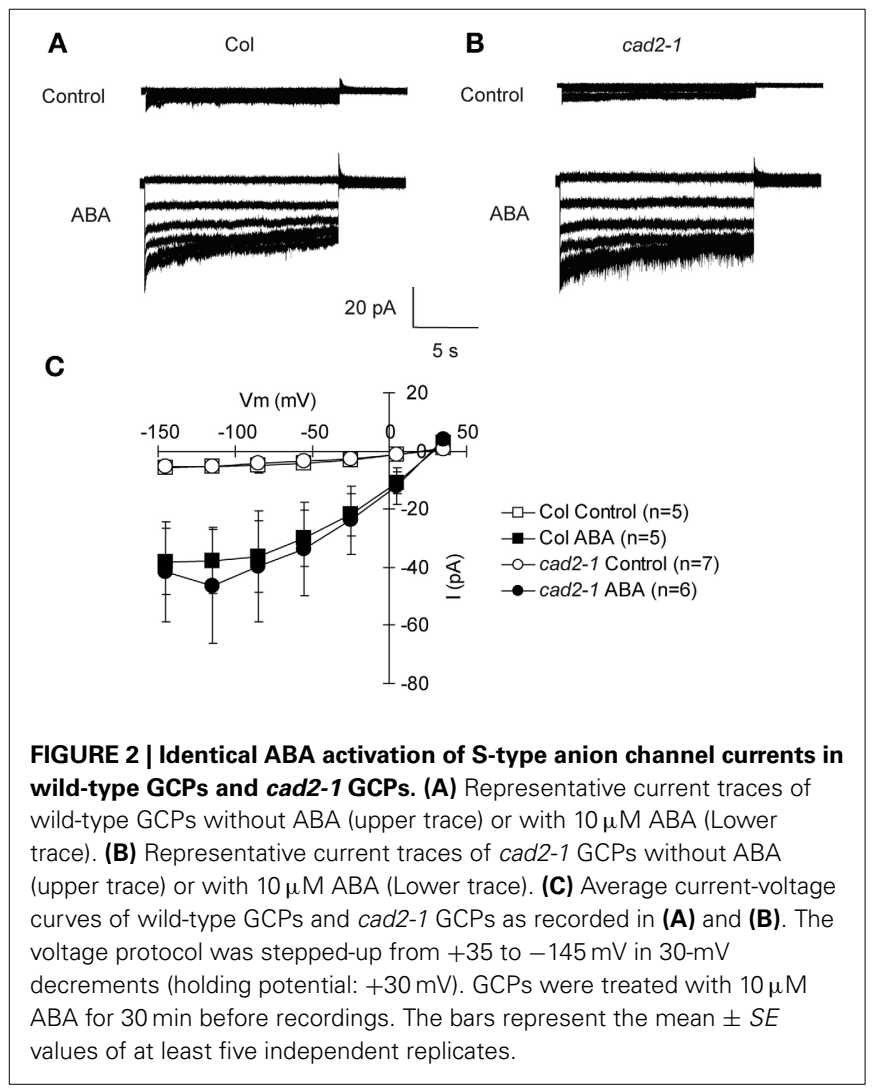

on ROS regulation of $\mathrm{I}_{\mathrm{Ca}}$ channels in guard cells. $\mathrm{H}_{2} \mathrm{O}_{2}$ at $1 \mathrm{mM}$ activates hyperpolarization-activated currents in both wild-type GCPs and cad2-1 GCPs (Figure 3). The $\mathrm{H}_{2} \mathrm{O}_{2}$ activation of $\mathrm{I}_{\mathrm{Ca}}$ currents was enhanced in cad2-1 GCPs compared to wild-type GCPs $\left(P<0.018\right.$ for $\mathrm{Col} \mathrm{H}_{2} \mathrm{O}_{2}$ vs. cad2 $-1 \mathrm{H}_{2} \mathrm{O}_{2}$ at $-180 \mathrm{mV}$; Figure 3). To examine effects of the enhanced $\mathrm{H}_{2} \mathrm{O}_{2}$ activation of cad2-1 $\mathrm{I}_{\mathrm{Ca}}$ channels on $\mathrm{H}_{2} \mathrm{O}_{2}$-induced stomatal closure, we performed stomatal bioassay. Significant reduction of stomatal apertures was observed in $100 \mu \mathrm{M} \mathrm{H}_{2} \mathrm{O}_{2}$-treated cad2-1 mutant $\left(P<0.038\right.$ for cad2-1 Control vs. cad2-1 $\mathrm{H}_{2} \mathrm{O}_{2}$; Figure 4) but not wild type ( $P=0.13$ for $\mathrm{Col}$ Control vs. $\mathrm{Col} \mathrm{H}_{2} \mathrm{O}_{2}$; Figure 4). Moreover, we found that $\mathrm{H}_{2} \mathrm{O}_{2}$-induced stomatal closure in the cad2-1 mutant was significantly attenuated by a membrane permeable derivative of GSH, GSHmee $\left(P<0.047\right.$ for $\mathrm{H}_{2} \mathrm{O}_{2}$ without GSHmee vs. $\mathrm{H}_{2} \mathrm{O}_{2}$ with GSHmee; Figure $\left.\mathrm{S} 1\right)$. These results suggest that decreased GSH contents in cad2-1 guard cells confer enhanced stomatal response to $\mathrm{H}_{2} \mathrm{O}_{2}$.

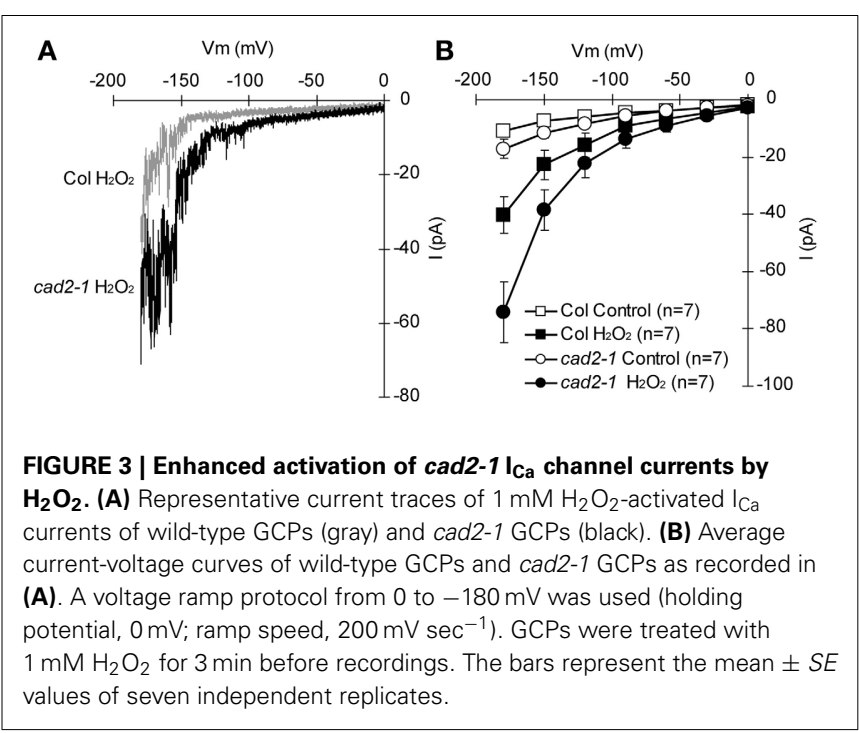

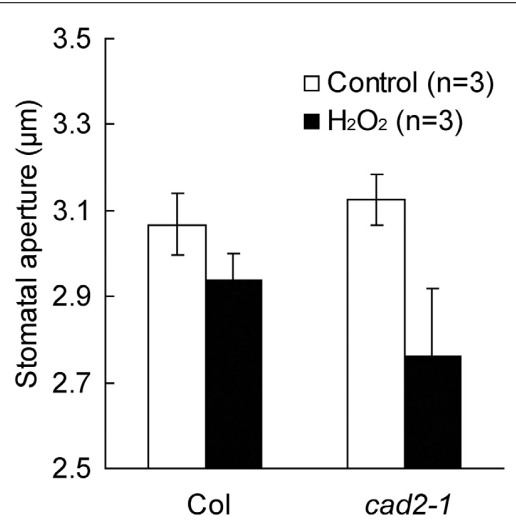

FIGURE 4 | Stomata of the cad2-1 mutant are more sensitive to exogenous $\mathrm{H}_{\mathbf{2}} \mathrm{O}_{\mathbf{2}}$ than those of wild type. Stomatal apertures of wild type and the cad2-1 mutant were measured $2 \mathrm{~h}$ after $100 \mu \mathrm{M} \mathrm{H}_{2} \mathrm{O}_{2}$ application. Twenty averages from three independent experiments (60 total stomata per bar) are shown. The bars represent the mean $\pm S E$ values. 


\section{THE cad2-1 MUTANT SHOWED ABA-INDUCED APOPLASTIC ROS ACCUMULATION IN LEAVES}

Accumulation of ROS in guard cell cytosol occurs during ABAinduced stomatal closure (Pei et al., 2000; Kwak et al., 2003). Previously we revealed that ABA-induced ROS accumulation in guard cell cytosol was not altered by GSH depletion (Jahan et al., 2008; Okuma et al., 2011; Akter et al., 2012). In addition to ROS produced by plasma membrane $\mathrm{NAD}(\mathrm{P}) \mathrm{H}$ oxidases, ROS produced by apoplastic enzymes such as cell-wall bound peroxidases participate in regulation of stomatal movement (An et al., 2008; Khokon et al., 2011; Hossain et al., 2013). To examine whether apoplastic ROS accumulation contributes to guard cell ABA signaling, we performed DAB staining experiments, which allows us to monitor ROS produced by apoplastic enzymes as well as ROS produced by NAD(P)H oxidases (Bindschedler et al., 2006; Khokon et al., 2011; Hossain et al., 2013). Wild-type leaves did not exhibit apoplastic ROS accumulation even when treated with high concentration of ABA $(50 \mu \mathrm{M})(P=0.72$ for Col Control vs. Col ABA; Figure 5). However, apoplastic ROS accumulation was significantly increased by ABA in cad2- 1 leaves $(P<0.04$ for cad2-1 Control vs. cad2-1 ABA; Figure 5). This result suggests that the accumulation of apoplastic ROS contributes to enhanced ABA response of cad2-1 guard cells.

\section{DISCUSSION}

Depletion of GSH enhances ABA-induced stomatal closure (Jahan et al., 2008; Okuma et al., 2011; Akter et al., 2012). However, the mechanism of how GSH regulates guard cell ABA signaling and involvement of GSH in controlling transpirational water loss have been unclear. In this manuscript, we tested involvement of GSH in controlling water loss from leaves and performed the detailed analysis of GSH regulation of guard cell ABA signaling using the GSH-deficient cad2-1 mutant. We confirmed that the cad2-1 mutation caused not only enhanced ABA-induced stomatal closure (Okuma et al., 2011) but also reduction of water loss from leaves (Figure 1). Hence manipulation of GSH level might provide a new strategy to improve plant drought tolerance.

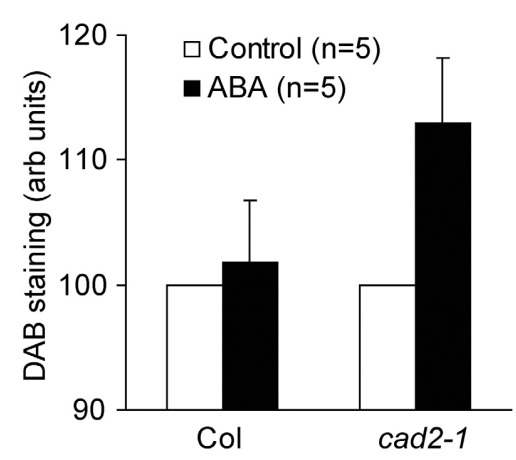

FIGURE 5 | ABA induces ROS accumulation in whole leaves of the cad2-1 mutant but not in whole leaves of wild type. Accumulation of ROS in whole leaves was monitored using DAB. The vertical scale represents the relative values of pixel intensity of DAB brown color when the values of $50 \mu \mathrm{M}$ ABA treated leaves are normalized to control value taken as 100 for each experiment. Each datum was obtained from at least four leaves. The bars represent the mean $\pm S E$ values of five independent replicates.
ABA activation of S-type anion channels is not altered in the cad2-1 guard cells (Figure 2). It has been suggested that the elevated $\left[\mathrm{Ca}^{2+}\right]_{\mathrm{cyt}}$ is required for ABA activation of S-type anion channels and ABA "primes" $\mathrm{Ca}^{2+}$ sensitivity of S-type anion channels (Siegel et al., 2009). In this study, we used the pipette solution where free $\left[\mathrm{Ca}^{2+}\right]$ was buffered to $2 \mu \mathrm{M}$ (See Materials and Methods). No obvious S-type anion current was observed in cad2-1 guard cells as well as wild-type guard cells without ABA pretreatment (Figure 2), suggesting that the cad2-1 mutation does not affect the priming state of $\mathrm{Ca}^{2+}$ sensitivity of S-type anion channels.

ABA induces guard cell $\left[\mathrm{Ca}^{2+}\right]_{\text {cyt }}$ elevation via activation of plasma membrane $\mathrm{I}_{\mathrm{Ca}}$ channels (Hamilton et al., 2000; Pei et al., 2000). Previously we found identical ABA activation of $\mathrm{I}_{\mathrm{Ca}}$ channels in wild-type and cad2-1 guard cells (Okuma et al., 2011). ROS mediates ABA activation of $I_{C a}$ channels (Pei et al., 2000; Murata et al., 2001; Kwak et al., 2003). In this study, we found enhanced response of cad2-1 $\mathrm{I}_{\mathrm{Ca}}$ channels to exogenous $\mathrm{H}_{2} \mathrm{O}_{2}$ (Figure 3). It was reported that ozone, an elicitor of ROS, induces biphasic $\left[\mathrm{Ca}^{2+}\right]_{c y t}$ elevation in seedlings and depletion of GSH by the cad2-1 mutation and buthionine sulphoximine, an inhibitor of $\gamma$-glutamylcysteine synthetase, enhances first peak of the ozone-induced biphasic $\left[\mathrm{Ca}^{2+}\right]_{\text {cyt }}$ response (Evans et al., 2005). These results suggest that GSH pools control sensitivity of plasma membrane $\mathrm{Ca}^{2+}$ permeable channels to ROS and downstream $\mathrm{Ca}^{2+}$ signals in plant cells.

Consistent with the enhancement of $\mathrm{I}_{\mathrm{Ca}}$ channel response to ROS, the cad2-1 mutant exhibits enhanced $\mathrm{H}_{2} \mathrm{O}_{2}$-induced stomatal closure (Figure 4). Note that depletion of GSH in guard cell cytosol is induced by ABA (Okuma et al., 2011), but not by $\mathrm{H}_{2} \mathrm{O}_{2}$ (Akter et al., 2013). These results imply that ABA sensitizes guard cells to ROS by decreasing GSH content via a pathway distinct from the ABA-mediated ROS production pathway (Figure 6).

Previously we reported identical cytosolic ROS accumulation induced by ABA in cytosol of wild-type and cad2-1 guard cells using $2^{\prime}, 7^{\prime}$-dichlorodihydrofluorescein diacetate (Okuma et al., 2011). It has been suggested that apoplastic ROS signals are also

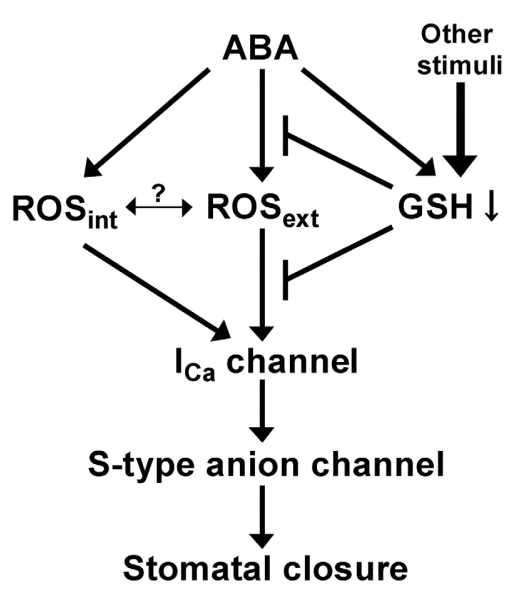

FIGURE 6 | A simplified model of GSH regulation of guard cell ABA signaling. 
involved in regulation of stomatal movement (An et al., 2008; Khokon et al., 2011; Hossain et al., 2013). In this study we monitored ROS accumulation in whole leaves using DAB. ABA induced ROS accumulation in whole leaves of the cad2-1 mutant but not in leaves of wild type (Figure 5). These results suggest that GSH depletion by the cad2-1 mutation affects ROS homeostasis in apoplastic space rather than that in guard cells during ABA-induced stomatal closure.

Based on the findings obtained in this study, we present one simplified signal model shown in Figure 6. ABA decreases guard cell GSH content via ROS-independent pathway (Akter et al., 2013). The decreased GSH content causes significant ROS accumulation in apoplast (Figure 5) and also sensitizes guard cell $\mathrm{I}_{\mathrm{Ca}}$ channels to apoplastic ROS (Figure 3) by unknown mechanism, resulting in enhanced stomatal response to ABA. In wild-type leaves, ABA decreases GSH content (Okuma et al., 2011) but does not induce significant apoplastic ROS accumulation (Figure 5), suggesting that the apoplastic ROS signal is employed to modulate ABA responsiveness of guard cells by other stimuli rather than by ABA signaling itself. Molecular mechanisms of how GSH regulates ROS sensitivity to plasma membrane $\mathrm{Ca}^{2+}$ permeable channels and apoplastic ROS homeostasis during ABA-induced stomatal closure would be investigated in the future.

\section{ACKNOWLEDGMENTS}

We thank Dr. Eiji Okuma (Okayama University) for critical reading of the manuscript.

\section{SUPPLEMENTARY MATERIAL}

The Supplementary Material for this article can be found online at: http://www.frontiersin.org/journal/10.3389/fpls.2013. 00472/abstract

Figure $\mathrm{S} 1$ | GSHmee attenuates enhanced stomatal response to $\mathrm{H}_{2} \mathrm{O}_{2}$ of the cad2-1 mutant. Detached rosette leaves of the cad2-1 mutant were incubated on stomatal assay buffer (see Materials and Methods) with or without $10 \mu \mathrm{M} \mathrm{GSHmee} \mathrm{for} 2 \mathrm{~h}$ in the light, followed by the addition of $100 \mu \mathrm{M} \mathrm{H}_{2} \mathrm{O}_{2}$. Stomatal apertures were measured $2 \mathrm{~h}$ after $\mathrm{H}_{2} \mathrm{O}_{2}$ application. Twenty averages from three independent experiments (60 total stomata per bar) are shown. The bars represent the mean $\pm S E$ values.

\section{REFERENCES}

Akter, N., Okuma, E., Sobahan, M. A., Uraji, M., Munemasa, S., Nakamura, Y., et al. (2013). Negative regulation of methyl jasmonate-induced stomatal closure by glutathione in Arabidopsis. J. Plant Growth Regul. 32, 208-215. doi: 10.1007/s00344-012-9291-7

Akter, N., Sobahan, M. A., Hossain, M. A., Uraji, M., Nakamura, Y., Mori, I. C., et al. (2010). The involvement of intracellular glutathione in methyl jasmonate signaling in Arabidopsis guard cells. Biosci. Biotechnol. Biochem. 74, 2504-2506. doi: $10.1271 / \mathrm{bbb} .100513$

Akter, N., Sobahan, M. A., Uraji, M., Ye, W., Hossain, M. A., Mori, I. C., et al. (2012). Effects of depletion of glutathione on abscisic acid- and methyl jasmonate-induced stomatal closure in Arabidopsis thaliana. Biosci. Biotechnol. Biochem. 76, 2032-2037. doi: 10.1271/bbb.120384

Allan, A. C., Fricker, M. D., Ward, J. L., Beale, M. H., and Trewavas, A. J. (1994). Two transduction pathways mediate rapid effects of abscisic acid in Commelina guard cells. Plant Cell 6, 1319-1328. doi: 10.2307/3869829

Allen, G. J., Kuchitsu, K., Chu, S. P., Murata, Y., and Schroeder, J. I. (1999). Arabidopsis abil-1 and abi2-1 phosphatase mutations reduce abscisic acidinduced cytosolic calcium rises in guard cells. Plant Cell 11, 1785-1798.
An, Z., Jing, W., Liu, Y. L., and Zhang, W. H. (2008). Hydrogen peroxide generated by copper amine oxidase is involved in abscisic acid-induced stomatal closure in Vicia faba. J. Exp. Bot. 59, 815-825. doi: 10.1093/jxb/erm370

Bindschedler, L. V., Dewdney, J., Blee, K. A., Stone, J. M., Asai, T., Plotnikov, J., et al. (2006). Peroxidase-dependent apoplastic oxidative burst in Arabidopsis required for pathogen resistance. Plant, J. 47, 851-863. doi: 10.1111/j.1365313X.2006.02837.x

Brandt, B., Brodsky, D. E., Xue, S., Negi, J., Iba, K., Kangasjärvi, J., et al. (2012). Reconstitution of abscisic acid activation of SLAC1 anion channel by CPK6 and OST1 kinases and branched ABI1 PP2C phosphatase action. Proc. Natl. Acad. Sci. U.S.A. 109, 10593-10598. doi: 10.1073/pnas.1116590109

Evans, N. H., McAinsh, M. R., Hetherington, A. M., and Knight, M. R. (2005). ROS perception in Arabidopsis thaliana: the ozone-induced calcium response. Plant J. 41, 615-626. doi: 10.1111/j.1365-313X.2004.02325.x

Fujii, H., Chinnusamy, V., Rodrigues, A., Rubio, S., Antoni, R., Park, S. Y., et al. (2009). In vitro reconstitution of an abscisic acid signalling pathway. Nature 462 , 660-664. doi: 10.1038/nature08599

Geiger, D., Scherzer, S., Mumm, P., Marten, I., Ache, P., Matschi, S., et al. (2010). Guard cell anion channel SLAC1 is regulated by CDPK protein kinases with distinct $\mathrm{Ca}^{2+}$ affinities. Proc. Natl. Acad. Sci. U.S.A. 107, 8023-8028. doi: 10.1073/pnas.0912030107

Geiger, D., Scherzer, S., Mumm, P., Stange, A., Marten, I., Bauer, H., et al. (2009). Activity of guard cell anion channel SLAC1 is controlled by drought-stress signaling kinase-phosphatase pair. Proc. Natl. Acad. Sci. U.S.A. 106, 21425-21430. doi: 10.1073/pnas.0912021106

Gilroy, S., Fricker, M. D., Read, N. D., and Trewavas, A. J. (1991). Role of calcium in signal transduction of Commelina guard cells. Plant Cell 3, 333-344. doi: $10.2307 / 3869209$

Grabov, A., and Blatt, M. R. (1998). Membrane voltage initiates $\mathrm{Ca}^{2+}$ waves and potentiates $\mathrm{Ca}^{2+}$ increases with abscisic acid in stomatal guard cells. Proc. Natl. Acad. Sci. U.S.A. 95, 4778-4783. doi: 10.1073/pnas.95.8.4778

Hamilton, D. W. A., Hills, A., Köhler, B., and Blatt, M. R. (2000). Ca ${ }^{2+}$ channels at the plasma membrane of stomatal guard cells are activated by hyperpolarization and abscisic acid. Proc. Natl. Acad. Sci. U.S.A. 97, 4967-4972. doi: 10.1073/pnas.080068897

Hossain, M. S., Ye, W., Hossan, M. A., Okuma, E., Uraji, M., Nakamura, Y., et al. (2013). Glucosinolate degradation products, isothiocyanates, nitriles, and thiocyanates, induce stomatal closure accompanied by peroxidase-mediated reactive oxygen species production in Arabidopsis thaliana. Biosci. Biotechnol. Biochem. 77, 977-983. doi: 10.1271/bbb.120928

Hu, H., Boisson-Dernier, A., Israelsson-Nordström, M., Böhmer, M., Xue, S., Ries, A., et al. (2010). Carbonic anhydrases are upstream regulators of CO2controlled stomatal movements in guard cells. Nat. Cell Biol. 12, 87-93. doi: $10.1038 /$ ncb2009

Jahan, M. S., Ogawa, K., Nakamura, Y., Shimoishi, Y., Mori, I. C., and Murata, Y. (2008). Deficient glutathione in guard cells facilitates abscisic acid-induced stomatal closure but does not affect light-induced stomatal opening. Biosci. Biotechnol. Biochem. 72, 2795-2798. doi: 10.1271/bbb.80407

Khokon, A. R., Okuma, E., Hossain, M. A., Munemasa, S., Uraji, M., Nakamura, Y., et al. (2011). Involvement of extracellular oxidative burst in salicylic acidinduced stomatal closure in Arabidopsis. Plant Cell Environ. 34, 434-443. doi: 10.1111/j.1365-3040.2010.02253.x

Kwak, J. M., Mori, I. C., Pei, Z. M., Leonhardt, N., Torres, M. A., Dangl, J. L., et al. (2003). NADPH oxidase AtrbohD and AtrbohF genes function in ROS-dependent ABA signaling in Arabidopsis. EMBO J. 22, 2623-2633. doi: 10.1093/emboj/cdg277

Lee, S. C., Lan, W., Buchanan, B. B., and Luan, S. (2009). A protein kinasephosphatase pair interacts with an ion channel to regulate ABA signaling in plant guard cells. Proc. Natl. Acad. Sci. U.S.A. 106, 21419-21424. doi: 10.1073/pnas.0910601106

Linder, B., and Raschke, K. (1992). A slow anion channel in guard cells, activating at large hyperpolarization, may be principal for stomatal closing. FEBS Lett. 313, 27-30. doi: 10.1016/0014-5793(92)81176-M

Ma, Y., Szostkiewicz, I., Korte, A., Moes, D., Yang, Y., Christmann, A., et al. (2009). Regulators of PP2C phosphatase activity function as abscisic acid sensors. Science 324, 1064-1068. doi: 10.1126/science. 1172408

Marten, H., Konrad, K. R., Dietrich, P., Roelfsema, M. R. G., and Hedrich, R. (2007). $\mathrm{Ca}^{2+}$-dependent and -independent abscisic acid activation of plasma 
membrane anion channels in guard cells of Nicotiana tabacum. Plant Physiol. 143, 28-37. doi: 10.1104/pp.106.092643

Maruta, T., Tanouchi, A., Tamoi, M., Yabuta, Y., Yoshimura, K., Ishikawa, T., et al. (2010). Arabidopsis chloroplastic ascorbate peroxidase isoenzymes play a dual role in photoprotection and gene regulation under photooxidative stress. Plant Cell Physiol. 51, 190-200. doi: 10.1093/pcp/pcp177

May, M. J., Vernoux, T., Leaver, C., van Montagu, M., and Inze, D. (1998). Glutathione homeostasis in plants: implications for environmental sensing and plant development. J. Exp. Bot. 49, 649-667. doi: 10.1093/jexbot/49. 321.649

McAinsh, M. R., Brownlee, C., and Hetherington, A. M. (1990). Abscisic acidinduced elevation of guard-cell cytosolic $\mathrm{Ca}^{2+}$ precedes stomatal closure. Nature 343, 186-188. doi: 10.1038/343186a0

Miao, Y., Lv, D., Wang, P., Wang, X. C., Chen, J., Miao, C., et al. (2006). Arabidopsis glutathione peroxidase functions as both a redox transducer and a scavenger in abscisic acid and drought stress responses. Plant Cell 18, 2749-2766. doi: $10.1105 /$ tpc. 106.044230

Munemasa, S., Hossain, M. A., Nakamura, Y., Mori, I. C., and Murata, Y. (2011). The Arabidopsis calcium-dependent protein kinase, CPK6, functions as a positive regulator of methyl jasmonate signaling in guard cells. Plant Physiol. 155, 553-561. doi: 10.1104/pp.110.162750

Munemasa, S., Oda, K., Watanabe-Sugimoto, M., Nakamura, Y., Shimoishi, Y., and Murata, Y. (2007). The coronatine-insensitive 1 mutation reveals the hormonal signaling interaction between abscisic acid and methyl jasmonate in Arabidopsis guard cells. Specific impairment of ion channel activation and second messenger production. Plant Physiol. 143, 1398-1407. doi: 10.1104/pp.106. 091298

Murata, Y., Pei, Z. M., Mori, I. C., and Schroeder, J. I. (2001). Abscisic acid activation of plasma membrane $\mathrm{Ca}^{2+}$ channels in guard cells requires cytosolic $\mathrm{NAD}(\mathrm{P}) \mathrm{H}$ and is differentially disrupted upstream and downstream of reactive oxygen species production in abil-1 and abi2-1 protein phosphatase $2 \mathrm{C}$ mutants. Plant Cell 13, 2513-2523. doi: 10.1105/tpc.13.11.2513

Negi, J., Matsuda, O., Nagasawa, T., Oba, Y., Takahashi, H., Kawai-Yamada, M., et al. (2008). $\mathrm{CO}_{2}$ regulator SLAC1 and its homologues are essential for anion homeostasis in plant cells. Nature 452, 483-486. doi: 10.1038/nature06720

Noctor, G., and Foyer, C. H. (1998). Ascorbate and glutathione: keeping active oxygen under control. Annu. Rev. Plant Physiol. Plant Mol. Biol. 49, 249-279. doi: 10.1146/annurev.arplant.49.1.249

Okuma, E., Jahan, M. S., Munemasa, S., Hossain, M. A., Muroyama, D., Islam, M. M., et al. (2011). Negative regulation of abscisic acid-induced stomatal closure by glutathione in Arabidopsis. J. Plant Physiol. 168, 2048-2055. doi: 10.1016/j.jplph.2011.06.002

Park, S. Y., Fung, P., Nishimura, N., Jensen, D. R., Fujii, H., Zhao, Y., et al. (2009). Abscisic acid inhibits type $2 \mathrm{C}$ protein phosphatases via the PYR/PYL family of START proteins. Science 324, 1068-1071. doi: 10.1126/science.1173041
Pei, Z. M., Kuchitsu, K., Ward, J. M., Schwarz, M., and Schroeder, J. I. (1997). Differential abscisic acid regulation of guard cell slow anion channels in Arabidopsis wild-type and abil and abi2 mutants. Plant Cell 9, 409-423. doi: $10.2307 / 3870491$

Pei, Z. M., Murata, Y., Benning, G., Thomine, S., Klüsener, B., Allen, G. J., et al. (2000). Calcium channels activated by hydrogen peroxide mediate abscisic acid signalling in guard cells. Nature 406, 731-734. doi: 10.1038/35021067

Schroeder, J. I., and Hagiwara, S. (1989). Cytosolic calcium regulates ion channels in the plasma membrane of Vicia faba guard cells. Nature 338, 427-430. doi: $10.1038 / 338427 \mathrm{a} 0$

Schroeder, J. I., and Hagiwara, S. (1990). Repetitive increases in cytosolic $\mathrm{Ca}^{2+}$ of guard cells by abscisic acid activation of nonselective $\mathrm{Ca}^{2+}$ permeable channels. Proc. Natl. Acad. Sci. U.S.A. 87, 9305-9309. doi: 10.1073/pnas.87.23.9305

Schroeder, J. I., and Keller, B. U. (1992). Two types of anion channel currents in guard cells with distinct voltage regulation. Proc. Natl. Acad. Sci. U.S.A. 89, 5025-5029. doi: 10.1073/pnas.89.11.5025

Siegel, R. S., Xue, S., Murata, Y., Yang, Y., Nishimura, N., Wang, A., et al. (2009). Calcium elevation-dependent and attenuated resting calciumdependent abscisic acid induction of stomatal closure and abscisic acid-induced enhancement of calcium sensitivities of S-type anion and inward-rectifying $\mathrm{K}$ channels in Arabidopsis guard cells. Plant J. 59, 207-220. doi: 10.1111/j.1365313X.2009.03872.x

Vahisalu, T., Kollist, H., Wang, Y. F., Nishimura, N., Chan, W. Y., Valerio, G., et al. (2008). SLAC1 is required for plant guard cell S-type anion channel function in stomatal signalling. Nature 452, 487-491. doi: 10.1038/nature06608

Conflict of Interest Statement: The authors declare that the research was conducted in the absence of any commercial or financial relationships that could be construed as a potential conflict of interest.

Received: 12 August 2013; paper pending published: 03 October 2013; accepted: 31 October 2013; published online: 20 November 2013.

Citation: Munemasa S, Muroyama D, Nagahashi H, Nakamura Y, Mori IC and Murata Y (2013) Regulation of reactive oxygen species-mediated abscisic acid signaling in guard cells and drought tolerance by glutathione. Front. Plant Sci. 4:472. doi: 10.3389/fpls.2013.00472

This article was submitted to Plant Physiology, a section of the journal Frontiers in Plant Science.

Copyright (c) 2013 Munemasa, Muroyama, Nagahashi, Nakamura, Mori and Murata. This is an open-access article distributed under the terms of the Creative Commons Attribution License (CC BY). The use, distribution or reproduction in other forums is permitted, provided the original author(s) or licensor are credited and that the original publication in this journal is cited, in accordance with accepted academic practice. No use, distribution or reproduction is permitted which does not comply with these terms. 